\title{
Tuning the Performance and the Stability of Porous Hollow PtNi/C Nanostructures for the Oxygen Reduction Reaction
}

\author{
Laetitia Dubau, ${ }^{*}{ }^{\dagger, \ddagger}$ Tristan Asset, ${ }^{\dagger \dagger}$ Raphaël Chattot, ${ }^{\dagger, \ddagger}$ Céline Bonnaud, ${ }^{\dagger, \ddagger}$ Victor Vanpeene, ${ }^{\dagger \dagger}$ \\ Jaysen Nelayah, $^{\perp}$ and Frédéric Maillard ${ }^{*}, \dagger, \ddagger$ \\ ${ }^{\dagger}$ University of Grenoble Alpes, LEPMI, F-38000 Grenoble, France \\ ${ }^{\ddagger}$ CNRS, LEPMI, F-38000 Grenoble, France \\ ${ }^{\perp}$ Laboratoire Matériaux et Phénomènes Quantiques (MPQ), UMR 7162 CNRS \& Université Paris-Diderot, Bâtiment Condorcet, 4 \\ rue Elsa Morante, F-75205 Paris Cedex 13, France
}

\section{Supporting Information}

ABSTRACT: Due to their increased surface area to volume ratio and molecular accessibility, microporous and mesoporous materials are a promising strategy to electrocatalyze the cathodic oxygen reduction reaction (ORR), the key reaction in proton-exchange membrane fuel cells (PEMFC). Here, we synthesized and provided atomically resolved pictures of porous hollow $\mathrm{PtNi} / \mathrm{C}$ nanocatalysts, investigated the elemental distribution of $\mathrm{Ni}$ and $\mathrm{Pt}$ atoms, measured the $\mathrm{Pt}$ lattice contraction, and correlated these observations to their ORR activity. The best porous hollow $\mathrm{PtNi} / \mathrm{C}$ nanocatalyst achieved 6 and 9-fold enhancement in mass and specific

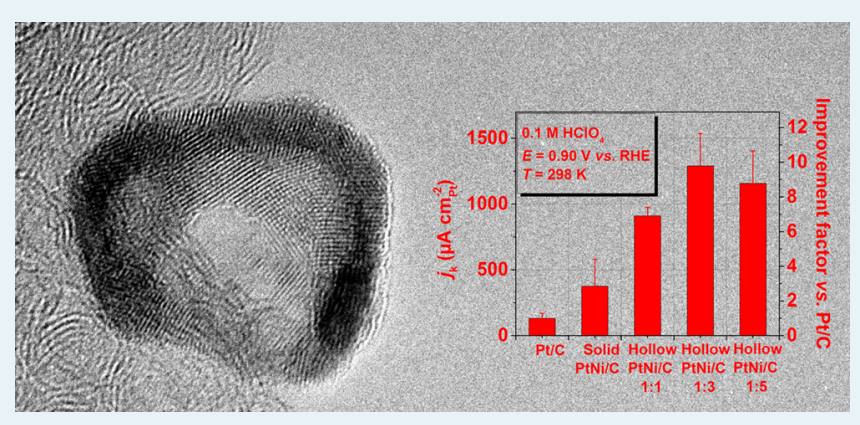
activity for the ORR, respectively over standard solid Pt/C nanocrystallites of the same size. The catalytic enhancement was 4 and 3-fold in mass and specific activity, respectively, over solid $\mathrm{PtNi} / \mathrm{C}$ nanocrystallites with similar chemical composition, $\mathrm{Pt}$ lattice contraction, and crystallite size. Furthermore, $100 \%$ of the initial mass activity at $E=0.90 \mathrm{~V}$ vs RHE $\left(0.56 \mathrm{~A} \mathrm{mg}^{-1} \mathrm{Pt}\right)$ of the best electrocatalyst was retained after an accelerated stress test composed of 30000 potential cycles between 0.60 and $1.00 \mathrm{~V}$ vs RHE ( $\left.0.1 \mathrm{M} \mathrm{HClO}_{4} T=298 \mathrm{~K}\right)$, therefore meeting the American Department of Energy targets for 2017-2020 both in terms of mass activity and durability $\left(0.44 \mathrm{~A} \mathrm{mg}^{-1} \mathrm{Pt}\right.$, mass activity losses $\left.<40 \%\right)$. The better catalytic activity for the ORR of hollow $\mathrm{PtNi} / \mathrm{C}$ nanocatalysts is ascribed to (i) their opened porosity, (ii) their preferential crystallographic orientation ("ensemble effect"), and (iii) the weakened oxygen binding energy induced by the contracted Pt lattice parameter ("strain effect").

KEYWORDS: platinum, hollow nanoparticles, galvanic replacement, oxygen reduction reaction, proton exchange membrane fuel cell, nanoporosity, durability

\section{INTRODUCTION}

Highly dispersed nanomaterials are widely used in heterogeneous catalysis to improve the surface area to volume ratio, and thus to provide cost savings. Because they exhibit unusual chemical and physical properties, different from those of the bulk material, the catalytic properties of nanoparticles are unique. It is well-established that a change in size of a metal nanoparticle results into: (i) a variation of the mean coordination number, ${ }^{1}$ (ii) a change of the equilibrium shape, ${ }^{2}$ (iii) a shift of the $d$-band center relative to the Fermi level, ${ }^{2-5}$ and (iv) an expansion or a contraction of the lattice parameter. ${ }^{6,7}$ Strikingly, despite specific cases such as the oxidation of carbon monoxide (CO) on Au nanoparticles, ${ }^{8,9}$ the intrinsic catalytic activity is usually depreciated when decreasing the metal nanoparticle size. ${ }^{4,5}$ This holds particularly true in proton-exchange membrane fuel cells (PEMFCs), where Ptbased nanoparticles supported onto a high-surface area carbon electrocatalyze the hydrogen oxidation reaction (HOR) and the oxygen reduction reaction (ORR). ${ }^{1,4,5,10-18}$ The specific activity (SA, the kinetic current normalized to a square centimeter of $\mathrm{Pt}$ ) for the ORR decreases by a factor of 4 going from bulk $\mathrm{Pt}$ to 2 nm-sized crystallites. ${ }^{12-14,18}$ Concomitantly, the mass activity (MA, the kinetic current per unit mass of $\mathrm{Pt}$ ) reaches a maximum at around $3-4 \mathrm{~nm}$. This trend is believed to be related to the increasing surface fraction of undercoordinated sites (edges, corners and vertices), which bind strongly to the ORR intermediates $(\mathrm{OH}, \mathrm{OOH}$, and O)..$^{1,11,15,18,19}$ The high fraction of undercoordinated sites also depreciates the long-term stability of the smallest Pt-based/C nanocrystallites (their higher surface energy causes increased driving force for dissolution and faster electrochemical dissolution kinetics). ${ }^{20}$ In consequence, metal nanocrystallites ca. 4-5 $\mathrm{nm}$ in size represent the best compromise between

Received: April 9, 2015

Revised: July 27, 2015

Published: July 28, 2015 
ORR activity and stability to date, and only new catalyst architectures may allow changing the picture.

In the past decade, Pt-transition metal alloy nanoparticles (Pt-M/C where $\mathrm{M}$ is an early or late ${ }^{21-26}$ transition metal) revealed great potential to accelerate the ORR kinetics. The catalytic enhancement over pure $\mathrm{Pt} / \mathrm{C}$ has been attributed to the weakening of the chemisorption energies of the ORR intermediates via strain ${ }^{21,27-30}$ and ligand ${ }^{31-33}$ effects. Unfortunately, whatever their initial structure (alloy, core-shell, skin/skeleton type electrocatalysts), considerable losses in catalytic activity were observed during long-term PEMFC operation. $^{34-39}$ Combined physical, chemical, and electrochemical techniques bridged these losses to the (i) decreased intrinsic catalytic activity due to $M$ dissolution and the formation of a thick Pt-enriched shell covering the initial Pt$\mathrm{M} / \mathrm{C}$ electrocatalyst, ${ }^{34-36,40-42}$ (ii) depreciated $\mathrm{H}^{+} / \mathrm{O}_{2}$ masstransport properties of the catalytic layer ionomer/proton exchange membrane (PEM), ${ }^{43-45}$ and (iii) enhanced formation of radical species in the PEM. ${ }^{43}$ In this context, we and other groups showed that, under specific PEMFC aging conditions, the dissolution of $\mathrm{Co}$ atoms from $\mathrm{Pt}_{3} \mathrm{Co} / \mathrm{C}$ nanoparticles leads to the formation of hollow Pt-rich nanostructures (i.e., containing a Pt-rich shell surrounding a central void) with enhanced ORR activity. ${ }^{36-38,40}$ The formation of these nanostructures was accounted for by a nanoscale Kirkendall effect, which is a vacancy-mediated diffusion mechanism in binary Pt-M alloys or M-core@Pt-shell materials driven by the faster interdiffusion of one element relative to the other. ${ }^{46-51}$

Taking inspiration from the structural and chemical changes occurring on $\mathrm{Pt}_{3} \mathrm{Co} / \mathrm{C}$ nanoparticles during real PEMFC life, we recently synthesized hollow $\mathrm{PtCo} / \mathrm{C}^{38}$ or $\mathrm{PtNi} / \mathrm{C}^{52}$ nanocrystallites via a one-pot process involving galvanic replacement (an electrochemical process in which the oxidation of the non-noble metal nanocrystallites provides electrons for the deposition of $\mathrm{Pt}^{\mathrm{z+}}$ ions onto their outer surface) and the nanoscale Kirkendall effect. In a typical synthesis, $\mathrm{Pt}\left(\mathrm{NH}_{3}\right)_{4} \mathrm{Cl}_{2}$. $\left(\mathrm{H}_{2} \mathrm{O}\right), \mathrm{NiCl}_{2} \cdot\left(6 \mathrm{H}_{2} \mathrm{O}\right)$, and $\mathrm{NaBH}_{4}$ are mixed with Vulcan $\mathrm{XC72R}$, ethanol, and deionized water (Figure 1). Based on

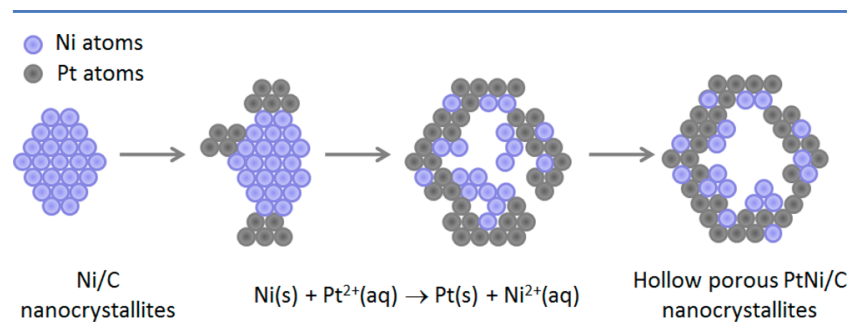

Figure 1. Schematic illustration of the procedure used to synthesize hollow Pt-rich nanoparticles. As described in the Experimental Section, all the chemical compounds are mixed simultaneously but Ni-rich/C nanocrystallites are believed to form first.

recent results from Shan et al., ${ }^{53} \mathrm{Ni}-\mathrm{B} / \mathrm{C}$ compounds are believed to form first, therefore acting as sacrificial templates for the deposition of $\mathrm{Pt}$ atoms via galvanic replacement. The deposition of $\mathrm{Pt}$ atoms likely proceeds on preferential regions of the sacrificial Ni-rich/C nanoparticles yielding nanometresized $\mathrm{PtNi} / \mathrm{C}$ clusters, which grow in close proximity to each other, and coalesce as the reduction of $\mathrm{Pt}^{2+}$ ions proceeds. Ultimately, an acid leaching treatment $(22 \mathrm{~h}$ in a stirred $1 \mathrm{M}$ $\mathrm{H}_{2} \mathrm{SO}_{4}$ solution at $T=293 \mathrm{~K}$ ) ensures the dissolution of unreacted Ni-rich regions and the formation of Pt-enriched surface layers.
This study describes the synthesis and the atomic-scale characterization of hollow $\mathrm{PtNi} / \mathrm{C}$ nanoparticles with different metal shell thickness and different size of the central cavity. These nanocatalysts combine opened porosity, compressed $\mathrm{Pt}$ lattice constant, and preferential crystallographic orientation, which result in 6 and 9-fold enhancement in mass and specific activity for the ORR, respectively over standard solid Pt/C nanocrystallites of the same size.

\section{RESULTS AND DISCUSSION}

Figure 2 displays high resolution high angle annular dark field scanning transmission electron microscopy (HAADF-STEM)
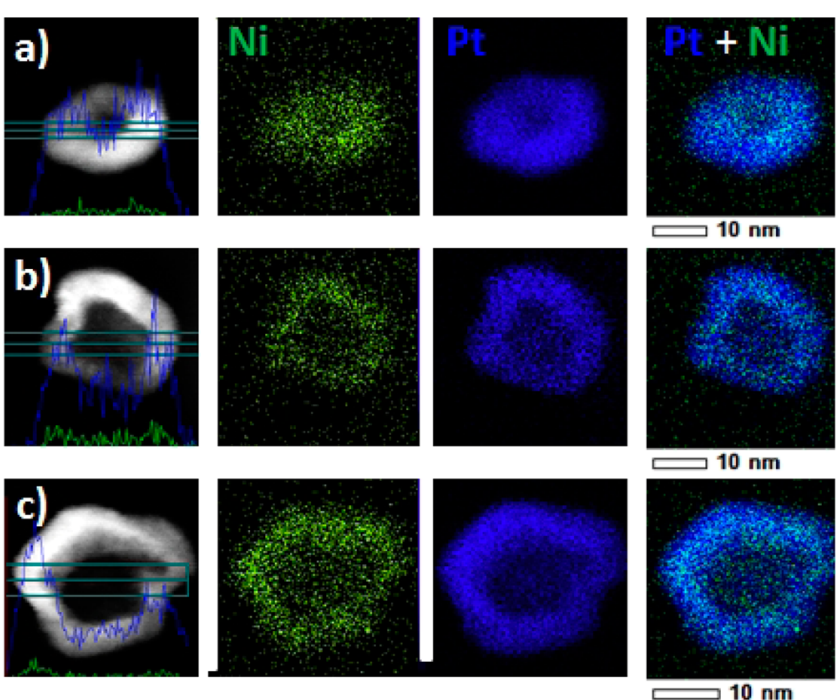

Figure 2. HAADF-STEM images, line scan analysis, and X-EDS elemental maps of hollow PtNi/C nanoparticles. The Pt:Ni stoichiometry in the initial metal salt precursor solution was (a) $1: 1$, (b) 1:3, and (c) 1:5. More HAADF-STEM images can be found in Supplementary Figure S1.

images, line-scan analyses, and X-ray energy dispersive spectroscopy (X-EDS) elemental maps of the electrocatalysts synthesized by varying the $\mathrm{Pt}: \mathrm{Ni}$ atomic ratio in the initial metal salt precursor solution from 1:1 to $1: 5$ (note that the $\mathrm{Pt}^{2+}$ concentration was kept constant and only the $\mathrm{Ni}^{2+}$ concentration varied). More images and elemental maps can be found in Supplementary Figure S1.

The PtNi/C nanoparticles feature irregular shape, and sizes comprised between ca. 10 and $15 \mathrm{~nm}$. Their central portion is darker than their surface, therefore suggesting a core-shell or a hollow nanostructure. X-EDS global and line-scan analyses as well as elemental maps reveal that (i) hollow-type $\mathrm{PtNi} / \mathrm{C}$ nanoparticles largely predominate, (ii) $\mathrm{Ni}$ and $\mathrm{Pt}$ atoms are homogeneously distributed within the metal shell but, as a result of acid leaching, ${ }^{54}$ the surface and near-surface of the catalysts are enriched in $\mathrm{Pt}$, and (iii) whatever the Pt:Ni ratio in the metal salt precursor solution, the $\mathrm{Ni}$ content estimated by $\mathrm{X}$-EDS over eight different zones is close to 10 at \% (Table 1 ). The slightly larger $\mathrm{Ni}$ content found by atomic absorption spectrometry (AAS) confirms our former results that the electrocatalyst contains a small fraction of solid Ni-rich core@ Pt-rich shell nanoparticles. ${ }^{52}$ To demonstrate the catalytic advantages of a hollow nanoarchitecture, solid $\mathrm{PtNi} / \mathrm{C}$ nanoparticles with similar chemical composition, Pt lattice contraction and crystallite size were synthesized via a modified 
Table 1. Structural and Chemical Parameters of the Electrocatalysts Evaluated in This Work-Atomic Composition Determined by X-EDS or AAS and Pt Lattice Parameter Measured by X-ray Diffraction

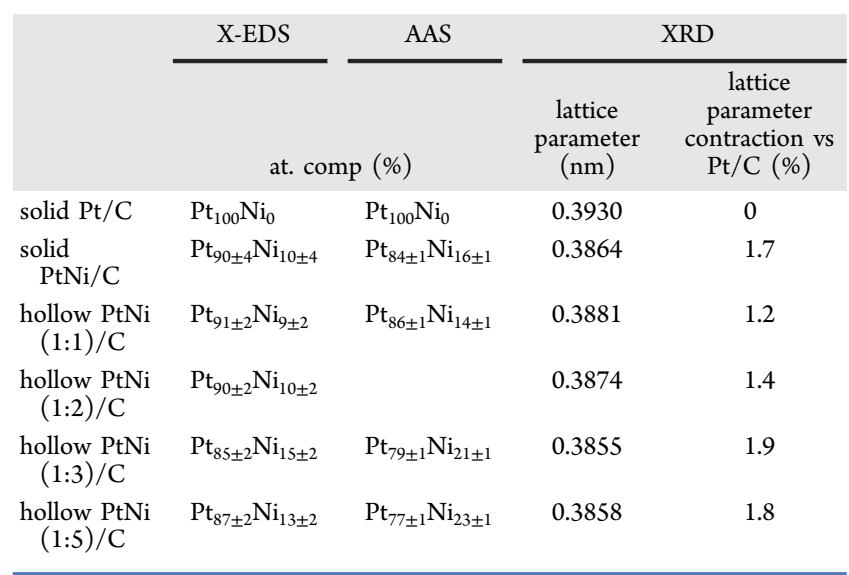

polyol method (see the Experimental Section). For the sake of clarity, in what follows, the hollow electrocatalysts will be referred to as Pt:Ni (initial stoichiometry)/C (e.g. PtNi (1:5)/ $\mathrm{C}$ when the Pt:Ni stoichiometry in the metal salt precursor solution was $1: 5$ ).

Figure 3 illustrates the morphological and structural changes occurring on the hollow $\mathrm{PtNi} / \mathrm{C}$ nanoparticles upon changing
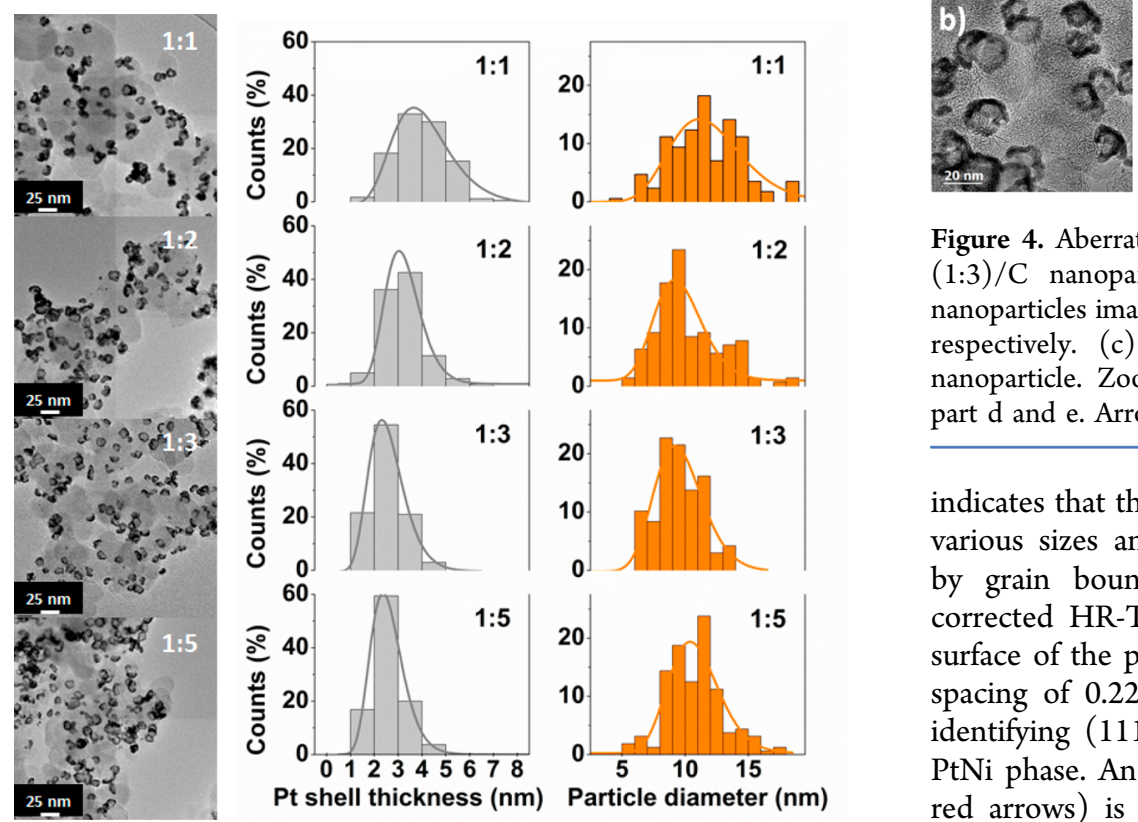

Table 2. Structural Parameters of the Electrocatalysts Evaluated in This Work ${ }^{a}$

\begin{tabular}{|c|c|c|c|c|}
\hline & XRD & & TEM & \\
\hline & $\begin{array}{c}\text { average } \\
\text { crystallite size }\end{array}$ & $d_{\text {shell }}(\mathrm{nm})$ & $d_{\text {void }}(\mathrm{nm})$ & $d_{\mathrm{ext}}(\mathrm{nm})$ \\
\hline solid $\mathrm{Pt} / \mathrm{C}$ & $2.2 \pm 0.2$ & & & $2.7 \pm 0.9$ \\
\hline solid $\mathrm{PtNi} / \mathrm{C}$ & $2.9 \pm 0.1$ & & & $2.2 \pm 0.7$ \\
\hline $\begin{array}{c}\text { hollow PtNi } \\
(1: 1) / \mathrm{C}\end{array}$ & $3.0 \pm 0.2$ & $3.9 \pm 1.0$ & $5.9 \pm 2.2$ & $13.6 \pm 2.9$ \\
\hline $\begin{array}{c}\text { hollow PtNi } \\
(1: 2) / \mathrm{C}\end{array}$ & $2.5 \pm 0.1$ & $3.1 \pm 0.9$ & $6.0 \pm 2.2$ & $12.3 \pm 2.9$ \\
\hline $\begin{array}{c}\text { hollow PtNi } \\
(1: 3) / \mathrm{C}\end{array}$ & $2.4 \pm 0.2$ & $2.5 \pm 0.7$ & $6.4 \pm 1.5$ & $11.4 \pm 1.9$ \\
\hline $\begin{array}{c}\text { hollow PtNi } \\
(1: 5) / \mathrm{C}\end{array}$ & $2.3 \pm 0.1$ & $2.6 \pm 0.7$ & $7.6 \pm 2.1$ & $12.8 \pm 2.3$ \\
\hline
\end{tabular}

$(1: 5) / \mathrm{C}$

${ }^{a}$ Average crystallite size estimated from XRD spectra, PtNi shell thickness, and size of the inner central void and of the outer metal layer statistically determined by TEM.

high-resolution transmission electron microscopy (HR-TEM). The HR-TEM image of PtNi (1:3)/C shown in Figure $4 \mathrm{c}$
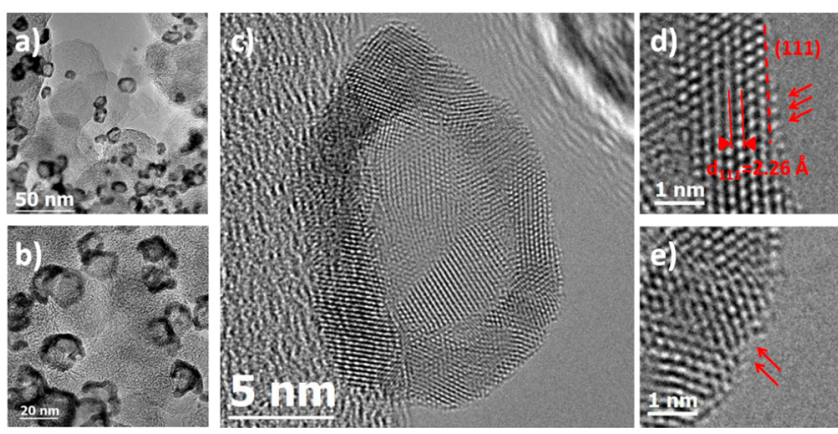

Figure 4. Aberration corrected HR-TEM images of the hollow PtNi (1:3)/C nanoparticles. (a and b) Assemblies of PtNi (1:3)/C nanoparticles imaged at 250000 and $400000 \times$ nominal magnification, respectively. (c) a HR-TEM image of a single $\mathrm{PtNi}(1: 3) / \mathrm{C}$ nanoparticle. Zoom-in images at the particle surface are shown in part $\mathrm{d}$ and e. Arrows are used to highlight different structural defects.

indicates that the metal shell is composed of nanocrystallites of various sizes and crystallographic orientations interconnected by grain boundaries. Figure $4 \mathrm{~d}$ and e shows aberrationcorrected HR-TEM images from two distinct regions of the surface of the particle shown in Figure 4c. In Figure 4d, the $d$ spacing of $0.226 \mathrm{~nm}$ averaged on 4-5 atomic rows allowed identifying (111) lattice planes in a face-centered cubic (fcc) PtNi phase. An adisland with monotonic height (indicated by red arrows) is also clearly visible, in agreement with former observations performed by Strmcnik et al. ${ }^{55}$ on $\mathrm{Pt}(\mathrm{hkl})$ single crystals. In Figure $4 \mathrm{e}$, we noticed the presence of grain boundaries in the metal shell along with a re-entrant corner (indicated by red arrows). Note that the broad distribution of interplanar distances and angles in this region prohibits any clear indexation of the different crystal planes in presence.

Aberration-correction HR-TEM images also revealed atomic details out of reach for conventional microscopes. For example, in Figure 5a, a discontinuity of the PtNi shell is evidenced in the center of the nanoparticle. Fourier transform (FT) analyses of the HR-TEM image in the center of the particle (red square zone) and in the metal shell (yellow square zone) are shown in insets (top-right and bottom-right, respectively). In the center of the nanoparticle, the FT pattern is structureless due to the 

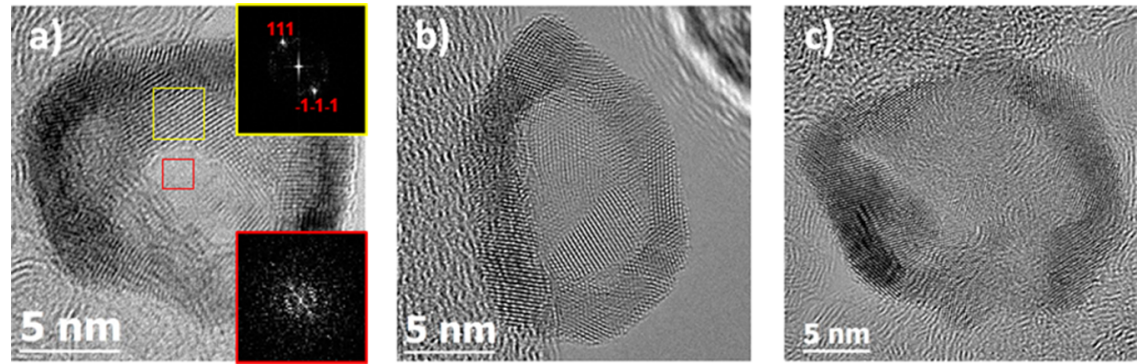

Figure 5. HR-TEM images of hollow porous $\mathrm{PtNi} / \mathrm{C}$ nanoparticles (initial Pt:Ni stoichiometry = 1:3) with pores ca. (a) 1.0, (b) 2.0, and (c) $>3.0$ $\mathrm{nm}$ in size. The FT patterns of the zones marked in part a are inserted in the right part of the figure (FFT of the center of the nanoparticle at the bottom right of the image).

Table 3. Theoretical and Measured Pt Specific Surface Area for the Electrocatalysts Evaluated in This Work

\begin{tabular}{lccccc} 
& solid Pt/C & solid PtNi/C & PtNi $(1: 1) / C$ & PtNi $(1: 3) / C$ & PtNi $(1: 5) / C$ \\
$d_{\text {void }}(\mathrm{nm})$ & & & $5.9 \pm 2.2$ & $6.4 \pm 1.5$ & $7.6 \pm 2.1$ \\
$d_{\text {ext }}(\mathrm{nm})$ & $2.7 \pm 0.9$ & $2.2 \pm 0.7$ & $13.6 \pm 2.9$ & $11.4 \pm 1.9$ & $12.8 \pm 2.3$ \\
$S_{\text {Pt,theo(shell) }}\left(\mathrm{m}^{2} \mathrm{~g}^{-1} \mathrm{Pt}\right)$ & 85.1 & 109.6 & 25.0 & 35.4 & 32.3 \\
$S_{\mathrm{Pt} \text {,theo(shell+void }}\left(\mathrm{m}^{2} \mathrm{~g}^{-1} \mathrm{Pt}\right)$ & & & 29.7 & 46.6 & 43.7 \\
$S_{\mathrm{Pt}, \mathrm{CO}}\left(\mathrm{m}^{2} \mathrm{~g}^{-1} \mathrm{Pt}\right)$ & $69.7 \pm 11.5$ & $37.5 \pm 3.7$ & $41.1 \pm 4.9$ & $43.7 \pm 3.4$ & $46.2 \pm 4.4$ \\
\hline
\end{tabular}

absence of metal in the corresponding zone. In the metal shell, the FT pattern shows the presence of (111) lattice reflections from $\mathrm{PtNi}$. These results provide clear evidence that a fraction of the hollow $\mathrm{PtNi} / \mathrm{C}$ nanocatalysts is nanoporous. The pores had a size comprised between 0.5 and $1.5 \mathrm{~nm}$ (Figure 5a), between 2 and $3 \mathrm{~nm}$ (Figure $5 \mathrm{~b}$ ) or were larger than $3 \mathrm{~nm}$ (Figure 5c), and are advantageous for catalytic activity since they create a possibility for oxygen molecules to access the inner surface (i.e. the surface of the central void). Occasionally, some nanopores merged; therefore breaking the hollow nanostructure and causing the formation of " $\mathrm{C}$ " shaped nanoparticles with irregular walls (see the low magnification image in Figure 4b). To avoid the fragmentation of the hollow nanoparticles into solid elongated "C" shaped fragments, no catalyst with initial Pt:Ni stoichiometry smaller than 1:5 was synthesized.

To confirm that the inner surface (the surface of the central void) and the atoms located along the nanopores are electrochemically active, the $\mathrm{Pt}$ specific surface area of the synthesized electrocatalysts $\left(S_{\mathrm{Pt}, \mathrm{CO}}\right)$ was calculated using the coulometry of a $\mathrm{CO}_{\mathrm{ad}}$ stripping experiment and compared to the theoretical values calculated assuming cuboctahedral particle shape and a stoichiometry of $1 \mathrm{CO}$ molecule per $\mathrm{Pt}$ atom. Table 3 shows that, if only the outer surface is considered, the theoretical $\mathrm{Pt}$ specific surface area (" $S_{\mathrm{Pt} \text {,theo(shell) }}$ ") is $25-50 \%$ inferior to that measured experimentally $\left(S_{\mathrm{Pt}, \mathrm{CO}}\right)$. A good agreement with $S_{\mathrm{Pt}, \mathrm{CO}}$ is obtained when both the inner and the outer surfaces (" $\left.S_{\mathrm{Pt} \text {,theo(shell+void) }}\right)$ are considered electrochemically active (Table 3 ).

The fcc structure of the synthesized hollow and the solid $\mathrm{PtNi} / \mathrm{C}$ electrocatalysts was confirmed using XRD (Figure 6). For all nanoalloys, the X-ray reflections shifted toward larger $2 \theta$ angles, indicating a contracted $\mathrm{Pt}$ lattice parameter vs. solid $\mathrm{Pt}$ / $\mathrm{C}$ nanocrystallites of the same size. As shown by Table 1 , the $\mathrm{Pt}$ lattice parameter was contracted by ca. $1.2,1.9$, and $1.8 \%$ vs pure $\mathrm{Pt} / \mathrm{C}$ for initial Pt:Ni stoichiometries of $1: 1,1: 3$, and 1:5, respectively. Moreover, the similar Pt lattice constant measured on the solid PtNi/C and the hollow PtNi (1:3)/C and PtNi (1:5)/C electrocatalysts guaranteed a fair demonstration of the catalytic advantage provided by a hollow nanoarchitecture.

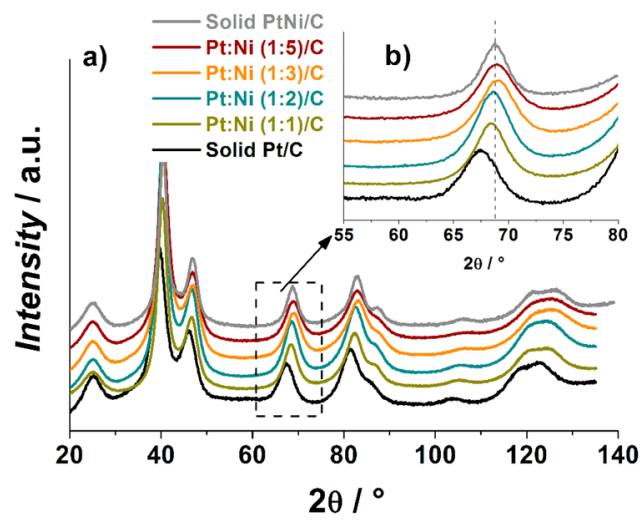

Figure 6. (a) X-ray diffraction patterns of the porous hollow PtNi/C and the reference solid $\mathrm{Pt} / \mathrm{C}$ and $\mathrm{PtNi} / \mathrm{C}$ electrocatalysts and (b) close-up in the $60^{\circ}<2 \theta<75^{\circ}$ region. The Pt:Ni stoichiometry in the metal salt precursor solution is indicated in the top left-hand side corner of the figure.

Insights into the surface reactivity of the porous hollow $\mathrm{PtNi} / \mathrm{C}$ nanoparticles were gained by probing the adsorption/ desorption of underpotentially deposited hydrogen $\left(\mathrm{H}_{\text {upd }}\right)$ between $0.05<E<0.40 \mathrm{~V}$ vs RHE. Similar $\mathrm{H}_{\text {upd }}$ adsorption/ desorption features were observed on the solid $\mathrm{Pt} / \mathrm{C}$ and $\mathrm{PtNi} /$ $\mathrm{C}$ electrocatalysts and the synthesized porous hollow $\mathrm{PtNi} / \mathrm{C}$ nanoparticles (Figure 7a): this confirms the conclusions derived from X-EDS elemental maps that the surface of the synthesized nanomaterials is essentially pure Pt. However, increased charge density was noticed in the region of "strongly-bound" hydrogen $(0.25<E<0.40 \mathrm{~V}$ vs RHE); therefore, pointing toward a larger surface fraction of $(100)+(111)$ facets on the hollow porous $\mathrm{PtNi} / \mathrm{C}$ nanoparticles vs the two reference materials. ${ }^{56-58}$

Preferential crystallographic orientation was probed by calculating the texture coefficients (TCs) of the synthesized nanocatalysts. The TC values were determined by comparing the intensities of the diffraction peaks monitored on the $\mathrm{PtNi}$ / C nanoparticles with those of the reference $\mathrm{Pt} / \mathrm{C} 20$ wt \% material: ${ }^{59}$ 

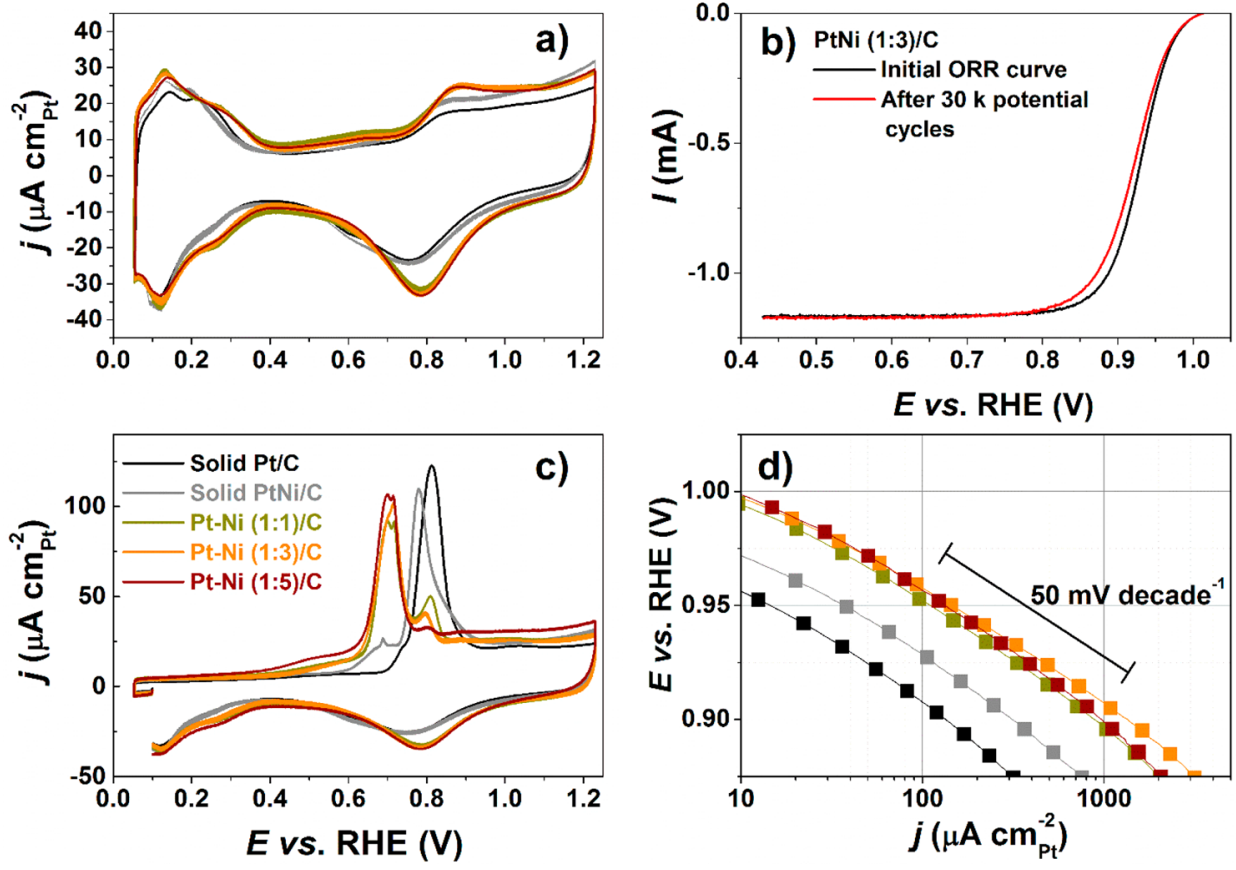

Figure 7. (a) Base and (c) $\mathrm{CO}_{\mathrm{ad}}$ stripping voltammograms measured on the porous hollow $\mathrm{PtNi} / \mathrm{C}$ and the reference solid $\mathrm{Pt} / \mathrm{C}$ and $\mathrm{PtNi} / \mathrm{C}$ electrocatalysts, (b) positive-going potential sweep voltammograms recorded on the hollow $\mathrm{PtNi}(1: 3) / \mathrm{C}$ nanoparticles before and after the accelerated stress test (AST), and (d) Tafel plots of the mass-transport corrected kinetic current obtained from the steady-state $I-E$ curves at $\omega=$ $1600 \mathrm{rpm}$ for the electrocatalysts evaluated in this work. Parts a and c were conducted in Ar-saturated $0.1 \mathrm{M} \mathrm{HClO}_{4}$ at $v=0.020 \mathrm{~V} \mathrm{~s}^{-1}$ without rotation of the electrode. Parts $\mathrm{b}$ and $\mathrm{d}$ were conducted in $\mathrm{O}_{2}$-saturated $0.1 \mathrm{M} \mathrm{HClO}_{4}$ at a potential sweep rate $v=0.005 \mathrm{~V} \mathrm{~s}^{-1}$. Other conditions: $T$ $=298 \pm 1 \mathrm{~K}$, Pt loading $=8.0 \mu \mathrm{g}$.

$$
\mathrm{TC}(h k l)=\frac{\frac{I(h k l)_{\mathrm{i}}}{I_{0}(h k l)_{\mathrm{i}}}}{\frac{1}{N} \sum_{i=1}^{n} \frac{I(h k l)_{\mathrm{i}}}{I_{0}(h k l)_{\mathrm{i}}}}
$$

with $I(h k l)_{i}$ as the observed intensity of the $(h k l)_{i}$ plane, $I_{0}(h k l)_{i}$ as the intensity of $(h k l)_{i}$ plane of the reference $\mathrm{Pt} / \mathrm{C}$ electrocatalyst, and $N$ as the total number of reflections taken into account. If for a certain plane, the ratio between the intensity of the diffraction peaks measured on the synthesized $\mathrm{PtNi} / \mathrm{C}$ and on the reference solid $\mathrm{Pt} / \mathrm{C}$ nanocatalyst is larger than unity, a preferential orientation exists along this direction. As shown by Table 4, porous hollow $\mathrm{PtNi} / \mathrm{C}$ nanoparticles, featuring opened porosity and thin Pt-shells, preferentially expose (111) and (100) facets.

In $\mathrm{CO}_{\mathrm{ad}}$ stripping experiments (Figure 7c), two peaks at $E=$ 0.72 and $0.76 \mathrm{~V}$ vs RHE, associated with $\mathrm{CO}_{\text {ad }}$ electrooxidation on surface defects and grain boundaries, ${ }^{59-62}$ dominate the reactivity of the porous hollow $\mathrm{PtNi} / \mathrm{C}$ electrocatalysts. This result confirms the conclusions derived from HR-TEM images that the synthesized hollow $\mathrm{PtNi} / \mathrm{C}$ nanocatalysts contain a

Table 4. Texture Coefficient Values Calculated for the Synthesized Porous Hollow PtNi/C Nanocatalysts Evaluated in This Work

\begin{tabular}{lcccc} 
& \multicolumn{4}{c}{ Crystallographic Planes Used for the Calculation } \\
\cline { 2 - 4 } & $(111)$ & $(200)$ & $(220)$ & $(311)$ \\
solid PtNi/C & 0.97 & 1.15 & 0.88 & 1.00 \\
$1: 1$ & 1.03 & 1.01 & 1.10 & 0.86 \\
$1: 2$ & 1.04 & 1.06 & 0.90 & 1.00 \\
$1: 3$ & 1.13 & 1.04 & 0.79 & 1.03 \\
$1: 5$ & 1.10 & 1.05 & 0.87 & 0.97
\end{tabular}

very large concentration of grain boundaries, and can easily be rationalized by considering the different Wigner-Seitz radii and the strong lattice mismatch between the deposited Pt atoms and the sacrificial $\mathrm{Ni}$ atoms. ${ }^{63}$ Indeed, according to the theory of elasticity, ${ }^{64,65}$ a stressed surface relaxes by introducing misfit dislocations and grain boundaries, while keeping its surface area (and thus its surface energy) constant.

Motivated by these unique structural characteristics, we then assessed the electrocatalytic activity for the ORR of the synthesized porous hollow $\mathrm{PtNi} / \mathrm{C}$ nanoparticles. The measurements were conducted under mass-transport control at $T=298$ $\mathrm{K}$ in $\mathrm{O}_{2}$-saturated $0.1 \mathrm{M} \mathrm{HClO}_{4}$. The kinetic current was determined after correction of Ohmic drop and mass-transport in solution, and expressed under the form of specific activity or mass activity at $E=0.95 \mathrm{~V}$ vs RHE (where the mass-transport was effectively corrected). For the sake of comparison with other studies, the kinetic current measured at $E=0.90 \mathrm{~V}$ vs RHE is also displayed in Table 5. As shown by Tafel plots (Figure $7 \mathrm{~d}$ ), the electrocatalyst with a Pt:Ni stoichiometry of $1: 3$ in the initial metal salt precursor solution was the more efficient. Independently of the considered electrode potential, this electrocatalyst achieved 6- and 9-fold enhancement in mass and specific activity for the ORR over standard solid Pt/C nanocrystallites of the same size, respectively. Similar catalytic performances were obtained for the catalyst with an initial Pt:Ni stoichiometry of $1: 5$, in agreement with its similar $\mathrm{Ni}$ content, Pt lattice contraction and crystallographic orientation. On the contrary, the electrocatalyst with an initial Pt:Ni stoichiometry of $1: 1$, for which preferential orientation was less marked and the Ni content was lower than in the two other porous hollow electrocatalysts performed worse. Note also that the catalytic enhancement was 4 and 3 -fold in mass and specific activity, respectively over solid $\mathrm{PtNi} / \mathrm{C}$ nanocrystallites of the 
Table 5. iR-Free ORR Kinetic Activity Parameters for the Synthesized Porous Hollow PtNi/C and the Reference Pt/C and $\mathrm{PtNi} / \mathrm{C}$ Electrocatalysts ${ }^{a}$

\begin{tabular}{cccccc} 
& \multicolumn{2}{c}{ at $E=0.95 \mathrm{~V}$ vs $\mathrm{RHE}$} & & \multicolumn{2}{c}{ at $E=0.90 \mathrm{~V}$ vs RHE } \\
\cline { 2 - 3 } \cline { 5 - 6 } & $\begin{array}{c}\text { specific } \\
\text { activity } \\
\left(\mu \mathrm{A} \mathrm{cm}^{-2} \mathrm{Pt}\right)\end{array}$ & $\begin{array}{c}\text { mass activity } \\
\left(\mathrm{mA} \mathrm{mg}^{-1} \mathrm{Pt}\right)\end{array}$ & & $\begin{array}{c}\text { specific } \\
\text { activity } \\
\left(\mu \mathrm{A} \mathrm{cm}^{-2} \mathrm{Pt}\right)\end{array}$ & $\begin{array}{c}\text { mass activity } \\
\left(\mathrm{mA} \mathrm{m}^{-1} \mathrm{Pt}\right)\end{array}$ \\
$\begin{array}{c}\text { solid } \\
\quad \mathrm{Pt} / \mathrm{C}\end{array}$ & $17 \pm 5$ & $12 \pm 2$ & $132 \pm 38$ & $90 \pm 20$ \\
$\begin{array}{c}\text { solid } \\
\quad \mathrm{PtNi} / \mathrm{C}\end{array}$ & $38 \pm 14$ & $14 \pm 5$ & & $376 \pm 204$ & $141 \pm 8$ \\
$1: 1$ & $114 \pm 11$ & $47 \pm 5$ & & $911 \pm 65$ & $374 \pm 27$ \\
$1: 3$ & $141 \pm 21$ & $62 \pm 9$ & & $1290 \pm 245$ & $564 \pm 101$ \\
$1: 5$ & $140 \pm 12$ & $65 \pm 5$ & & $1158 \pm 246$ & $535 \pm 102$
\end{tabular}

${ }^{a_{T}}$ The ORR curves were recorded in $\mathrm{O}_{2}$-saturated $0.1 \mathrm{M} \mathrm{HClO}_{4}$ at $\mathrm{T}=$ $298 \pm 1 \mathrm{~K}$ using a potential sweep rate $v=0.005 \mathrm{~V} \mathrm{~s}^{-1}$ and $\omega=1600$ rpm. Pt loading: $8.0 \mu \mathrm{g}$. Each data point is the average of at least three independent experiments.

same size, similar chemical composition ( $\mathrm{Ni}$ content ca. 15 at $\%)$, and Pt lattice constant. These results emphasize that three phenomena contribute to enhance the ORR activity on the porous hollow $\mathrm{PtNi} / \mathrm{C}$ electrocatalysts: (i) their opened porous architecture, (ii) a preferential crystallographic orientation ("ensemble effect"), and (iii) the weakened oxygen binding energy induced by the contracted Pt lattice parameter ("strain effect").

Lastly, accelerated stress tests (ASTs) were performed to investigate the structural stability and the long-term catalytic performance of the hollow $\mathrm{PtNi} / \mathrm{C}$ and the reference solid $\mathrm{Pt} /$ $\mathrm{C}$ nanoparticles (Figure 8). The AST consisted of 30000 (30 k) potential cycles between 0.60 and $1.00 \mathrm{~V}$ vs RHE at a sweep rate $v=0.05 \mathrm{~V} \mathrm{~s}^{-1}$ in $0.1 \mathrm{M} \mathrm{HClO}_{4}$ and $T=298 \mathrm{~K}$. We first remark that the ORR specific and mass activity slightly increased for the reference $\mathrm{Pt} / \mathrm{C}$ after aging. These results can be rationalized by considering the increase of the mean $\mathrm{Pt}$ particle size monitored by TEM (Figures S2 and S3), and the fact that the mass activity for the ORR is optimal for $\mathrm{Pt}$ nanoparticle sizes comprised between 3 and $4 \mathrm{~nm}^{4,5,14,18}$ in agreement with the recent findings of $\mathrm{Li}$ et al. ${ }^{66}$ in similar experimental conditions. Despite this slight improvement in catalytic activity, the catalytic trends remained unchanged, i.e. the porous hollow $\mathrm{PtNi} / \mathrm{C}$ electrocatalysts performed better than the reference $\mathrm{Pt} / \mathrm{C}$ even after 30000 potential cycles. A strong dependence of the long-term catalytic performance on the initial nanoparticle morphology was also noticed: slightly decreasing ORR activities were monitored for the catalysts with the thicker Pt-rich shell and the smallest central void (namely PtNi (1:1)/C and Pt:Ni (1:3)/C). On the contrary, both the ORR specific activity and the mass activity were increased on the aged porous hollow $\mathrm{PtNi} / \mathrm{C}$ nanoparticles with the larger central void $(\mathrm{PtNi}(1: 5) / \mathrm{C})$. Since the three hollow PtNi/C electrocatalysts feature similar $\mathrm{Ni}$ content in the fresh state (close to 10 at. \%, see Table 1), and after aging (close to 5 at $\%)$, the changes in surface reactivity cannot be attributed to the sole chemical changes. Rather, we argue that structural changes play a key role in the long term ORR performance. As shown by Figure 8, the enhancement in mass and specific activity over solid Pt/C nanocrystallites decreased to 2 and 4.5 -fold on the aged hollow $\mathrm{PtNi} / \mathrm{C}$ nanoparticles with the initial smallest central cavity (PtNi (1:1)/C), which had collapsed after 30000 potential cycles $(133 \mathrm{~h})$. On the contrary, the initial morphology, and thus the initial catalytic activity enhancement
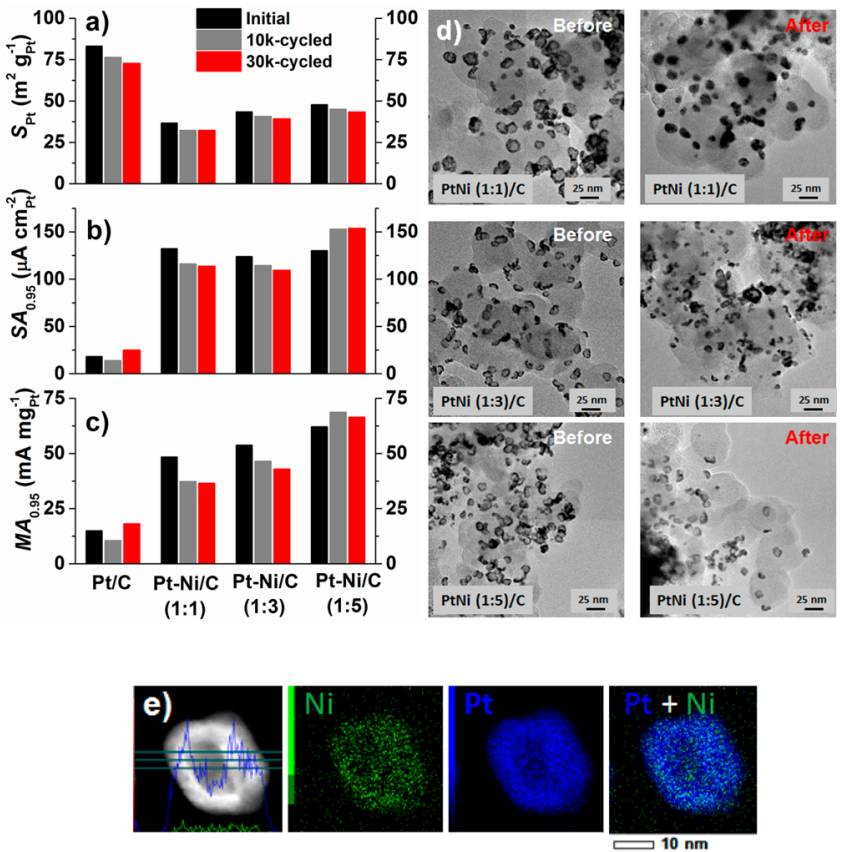

Figure 8. Time evolution of (a) the Pt specific surface area, (b) the ORR specific activity, and (c) the ORR mass activity during accelerated stress tests consisting of 30000 potential cycles between 0.60 and $1.00 \mathrm{~V}$ vs RHE at $v=0.05 \mathrm{~V} \mathrm{~s}^{-1}$. (d) Features of representative TEM images of the initial and the 30000 -cycled hollow $\mathrm{PtNi} / \mathrm{C}$ electrocatalysts. (e) HAADF image of a single hollow $\mathrm{PtNi} / \mathrm{C}$ nanoparticle with an initial Pt:Ni stoichiometry of $1: 3$ after 30000 potential cycles along with its elemental map. The Pt specific surface area was determined from $\mathrm{CO}_{\mathrm{ad}}$ stripping experiments. The activity for the ORR was evaluated from Ohmic drop and mass transportcorrected kinetic currents measured at $E=0.95 \mathrm{~V}$ vs $\mathrm{RHE}$ in $\mathrm{O}_{2}$ saturated $0.1 \mathrm{M} \mathrm{HClO}_{4}$. Potential sweep rate $0.005 \mathrm{~V} \mathrm{~s}^{-1} ; \omega=1600$ rpm; positive-going potential sweep from 0.40 to $1.05 \mathrm{~V}$ vs RHE; $T=$ $298 \pm 1 \mathrm{~K}$, Pt loading: $8.0 \mu \mathrm{g}$.

over pure $\mathrm{Pt} / \mathrm{C}$ nanocrystallites, were maintained for the porous hollow $\mathrm{PtNi} / \mathrm{C}$ nanoparticles with the largest central void (PtNi (1:5)/C). The PtNi (1:3)/C catalyst represented an intermediate case.

Studies are ongoing in our group to disentangle the role of the size of the central void, the degree of nanoporosity, the preferential crystallographic orientation, the initial Ni content, and the degree of contraction of the Pt lattice parameter and will be published in forthcoming papers.

\section{CONCLUSIONS}

In summary, hollow PtNi/C nanoparticles with tunable Pt-rich shell thickness and Pt lattice contraction were synthesized via a method involving the galvanic replacement, and the nanoscale Kirkendall effect. The best porous hollow $\mathrm{PtNi} / \mathrm{C}$ electrocatalyst achieved 6 and 9-fold enhancement in mass and specific activity for the ORR, respectively over standard solid $\mathrm{Pt} / \mathrm{C}$ nanocrystallites of the same crystallite size. The catalytic activity enhancement was more than 3 and 4-fold in specific and mass activity, respectively, over solid $\mathrm{PtNi} / \mathrm{C}$ nanoparticles having similar chemical composition, $\mathrm{Pt}$ lattice contraction, and crystallite size. Furthermore, $100 \%$ of the initial mass activity measured at $E=0.90 \mathrm{~V}$ vs $\operatorname{RHE}\left(0.56 \mathrm{~A} \mathrm{mg}^{-1} \mathrm{Pt}\right)$ was retained after an accelerated stress test composed of 30000 potential cycles between 0.60 and $1.00 \mathrm{~V}$ vs RHE, therefore meeting the American Department of Energy targets for 2017-2020 both in 
terms of mass activity and durability $\left(0.44 \mathrm{~A} \mathrm{mg}^{-1} \mathrm{Pt}\right.$, mass activity losses $<40 \%)$. The ORR activity and the robustness of the porous hollow $\mathrm{PtNi} / \mathrm{C}$ nanoparticles depended on the size of the central void and, to a less extent, on the Pt-rich shell thickness. These findings highlight the importance of nanoporosity on the catalytic enhancement for the ORR, and may be regarded as a first step toward the synthesis of more efficient Pt-based/C nanocatalysts.

\section{EXPERIMENTAL SECTION}

Reference Electrocatalyst. Pt nanoparticles supported on Vulcan XC72 with a weight fraction (wt \%) of $20 \%$ were purchased from E-TeK and used as a reference material. The number-averaged $\mathrm{Pt}$ nanoparticle size was $2.7 \pm 0.9 \mathrm{~nm}$. The electrocatalyst was used as-received without any further treatment.

Synthesis of Hollow Porous PtNi/C Nanoparticles. In a typical synthesis, a determined number of moles of Pt$\left(\mathrm{NH}_{3}\right)_{4} \mathrm{Cl}_{2} \cdot \mathrm{H}_{2} \mathrm{O}$ (Alfa Aesar, Specpure) and $\mathrm{NiCl}_{2} \cdot 6 \mathrm{H}_{2} \mathrm{O}$ (Fluka, > 98.0\%) was first mixed with $0.3 \mathrm{~g}$ Vulcan XC72R (Cabot), $10 \mathrm{~mL}$ of ethanol and $140 \mathrm{~mL}$ of deionized water (Millipore). An aqueous solution of $\mathrm{NaBH}_{4}$ (Aldrich 99.99\% $5.5 \mathrm{mmol}, 0.22 \mathrm{M}$ ) was then added at a rate of $5 \mathrm{~mL} \mathrm{~min}^{-1}$ and stirred for $1 \mathrm{~h}$ under magnetic stirring at room temperature $(293 \pm 2 \mathrm{~K})$. The resulting mixture was filtered, thoroughly washed by deionized water, and dried for $45 \mathrm{~min}$ at $T=383 \mathrm{~K}$. The catalysts powder was then acid-treated for $t=22 \mathrm{~h}$ in a stirred $1 \mathrm{M} \mathrm{H}_{2} \mathrm{SO}_{4}$ solution at $T=293 \mathrm{~K}$.

Synthesis of Solid PtNi/C Nanoparticles. Solid PtNi/C nanoparticles were prepared using a modified polyol method $^{67,68}$ The simultaneous reduction of a mixture of $\mathrm{Pt} /$ $\mathrm{Ni}$ precursors was realized in diluted ethylene glycol (EG) without any surfactant. First, the calculated amounts of $\mathrm{H}_{2} \mathrm{PtCl}_{6} \cdot 6 \mathrm{H}_{2} \mathrm{O}$ and $\mathrm{NiCl}_{2} \cdot 6 \mathrm{H}_{2} \mathrm{O}$ metal salts (Alfa Aesar) were dissolved in a vial containing a $20 \mathrm{~mL}$ mixture of deionized water and ethylene glycol (EG, EG:water volume ratio 1:1). An appropriate amount of carbon black support particles (Vulcan XC-72, Cabot) targeting $20 \mathrm{wt} \%$ Pt loading was then dispersed by sonication in a separated vial containing also $20 \mathrm{~mL}$ of $1: 1$ EG:water mixture. Then, the contents of each vials were mixed in $20 \mathrm{~mL}$ of pure EG, leading to a 2:1 EG:water volumic ratio. The $\mathrm{pH}$ of the obtained mixture was adjusted to 10 using a 0.5 $\mathrm{M} \mathrm{NaOH}$ solution (diluted in 1:1 EG:water mixture). The resulting suspension was kept under vigorous stirring for $t=1 \mathrm{~h}$ under argon atmosphere before being refluxed at $T=433 \mathrm{~K}$ for $t=3 \mathrm{~h}$. The solution was allowed to cool down to room temperature under air atmosphere for $t=12 \mathrm{~h}$ with continuous stirring. ${ }^{69}$ The $\mathrm{pH}$ of the mixture was then adjusted to 3 using a $0.5 \mathrm{M} \mathrm{H}_{2} \mathrm{SO}_{4}$ aqueous solution and left for $t=24$ extra hours. Finally, the solution was filtered and copiously washed with deionized water before being dried at $T=383 \mathrm{~K}$ for $t=1 \mathrm{~h}$. The resulting carbon supported PtNi catalyst was grinded using a mortar to obtain a fine powder.

Atomic Absorption Spectrometry. The metal content of each electrode was measured by atomic absorption spectrometry on an atomic absorption spectrometer (PinAAcle 900F, PerkinElmer). A $4 \mathrm{mg}$ portion of the cathode electrocatalyst was first digested in concentrated aqua regia $\left(3: 1 \mathrm{HCl}: \mathrm{HNO}_{3}\right.$ by volume) made from high purity acids (Suprapur, Merck) at $T=333 \mathrm{~K}$. An aliquot of this solution was then pipetted and diluted in Aqua Regia $(<1 \mathrm{M} \mathrm{HCl})$ so as to target $120 \mathrm{ppm}$ of platinum and $4 \mathrm{ppm}$ of nickel. The $\mathrm{Pt}$ and $\mathrm{Ni}$ atomic ratios were then determined by comparing three series of measure- ments and a calibration plot made from standard samples. For that purpose, one Pt-related $(\lambda=266 \mathrm{~nm})$ and two Ni-related $(\lambda=232 \mathrm{~nm})$ wavelengths were used.

X-ray Diffraction Measurements. The synthesized and reference electrocatalysts were analyzed using a PANalytical X’Pert Pro MPD vertical goniometer/diffractometer equipped with a diffracted-beam monochromator using $\mathrm{Cu}\left(\mathrm{K}_{\mathrm{a}}\right.$ mean $)$ radiation $(\lambda=0.15418 \mathrm{~nm})$ operating at $45 \mathrm{kV}$ and $40 \mathrm{~mA}$. The $2 \theta$ angle extended from $10^{\circ}$ to $125^{\circ}$ and varied using a step size of $0.033^{\circ}$ accumulating data for $525 \mathrm{~s}$. The lattice contraction was estimated from the position of the (111), (220), and (311) diffraction peaks on the reference $\mathrm{Pt} / \mathrm{C}$ and the synthesized $\mathrm{PtNi} / \mathrm{C}$ materials. The average $\mathrm{XRD}$ crystallite size was obtained from a fit of the $\operatorname{Pt}(220)$ peak using the DebyeScherrer equation.

Electron Microscopy. The electrocatalysts was examined with a Jeol 2010 TEM operated at $200 \mathrm{kV}$ with a point to point resolution of $0.19 \mathrm{~nm}$ to build the particle size distribution of the catalysts, based on TEM images obtained at high magnifications $(200000 \times)$. Since the synthesized $\mathrm{PtNi} / \mathrm{C}$ nanoparticles were irregularly shaped, the number of monolayers in the Pt-rich shell was estimated using the maximum Feret diameter of the outer-metal layer and of the inner core, after consideration of all possible diameters. The difference between the maximum Feret radius of the outermetal layer and of the inner core was the shell thickness. For the reference spherical-shaped $\mathrm{Pt} / \mathrm{C}$ electrocatalyst, a classical particle size distribution was established and the numberaveraged diameter:

$$
\left(\bar{d}_{\mathrm{N}}=\frac{\sum_{i=1}^{n} l_{i} d_{i}}{\sum_{i=1}^{n} l_{i}}\right)
$$

was determined $\left(l_{\mathrm{i}}\right.$ stands for the number of particles having a diameter $d_{\mathrm{i}}$ ).

$\mathrm{X}$-ray energy-dispersive spectroscopy (X-EDS) elemental maps were acquired using a JEOL $2100 \mathrm{~F}$ microscope operated at $200 \mathrm{kV}$ and equipped with a SDD Centurio retractable detector. The X-EDS spectra were recorded on individual nanoparticles by scanning the beam in a square region adjusted to the particle size. The quantitative analyses were performed on Pt $\mathrm{L}$ and Ni $\mathrm{K}$ lines using the $K$-factor provided by the JEOL software. Representative X-EDS elemental maps and examples of profile intensity for $\mathrm{Pt}$ and $\mathrm{Ni}$ elements are provided in Figure S1.

Aberration-Corrected Transmission Electron Microscopy. High resolution transmission electron microscopy (HRTEM) images were acquired using a JEM-ARM 200F (JEOL) microscope equipped with a cold-field emission gun and an image aberration corrector. ${ }^{70}$ In the present study, the microscope was operated at an accelerating voltage of $200 \mathrm{kV}$ with the spherical aberration set at $-671.9 \mathrm{~nm}$ after aberration correction. The sample for HR-TEM imaging was prepared by depositing the as-synthesized dried $\mathrm{PtNi} / \mathrm{C}$ nanoparticles on a carbon-coated lacey TEM grid from SPI Supplies.

Electrochemical Measurements in Liquid Electrolyte. All the glassware accessories used in this study were first cleaned by soaking in a $\mathrm{H}_{2} \mathrm{SO}_{4}: \mathrm{H}_{2} \mathrm{O}_{2}$ mixture for at least $12 \mathrm{~h}$ and thoroughly washing with ultrapure water. The $1 \mathrm{M} \mathrm{H}_{2} \mathrm{SO}_{4}$ solution used for acid-leaching was prepared with Milli-Q water (Millipore, 18.2 $\mathrm{M} \Omega \mathrm{cm}$, total organic compounds $<3 \mathrm{ppb}$ ) and $\mathrm{H}_{2} \mathrm{SO}_{4} 96$ wt \% (Suprapur, Merck). 
The electrochemical measurements were conducted using an Autolab PGSTAT302N in a custom-made four-electrode electrochemical cell thermostated at $T=298 \pm 1 \mathrm{~K}$. Fresh electrolyte solution $\left(0.1 \mathrm{M} \mathrm{HClO}_{4}\right)$ was daily prepared with Milli-Q water (Millipore, 18.2 $\mathrm{M} \Omega \mathrm{cm}$, total organic compounds <3 ppb) and $\mathrm{HClO}_{4} 96$ wt \% (Suprapur, Merck). The counterelectrode was a glassy carbon plate, and the reference electrode was a commercial reversible hydrogen electrode (Hydroflex, Gaskatel $\mathrm{GmbH}$ ) connected to the cell via a Luggin capillary. A Pt wire connected to the reference electrode was used to filter the high frequency electrical noise and to avoid disturbing the low frequency electrical measurements. More details on the dual-reference system used in this work can be found in ref 71 .

To prepare the working electrodes, a suspension containing $10 \mathrm{mg} \mathrm{Pt} / \mathrm{C}$ from E-TeK or as-synthesized PtNi/C, $108 \mu \mathrm{L}$ of 5 wt \% Nafion solution (Electrochem. Inc.), $642 \mu \mathrm{L}$ of isopropanol, and $1.8 \mathrm{~mL}(18.2 \mathrm{M} \Omega \mathrm{cm})$ of deionized water (MQ-grade, Millipore) was prepared. After sonication for 15 min, $10 \mu \mathrm{L}$ of the suspension was pipetted onto a glassy carbon disk, and sintered for $5 \mathrm{~min}$ at $T=383 \mathrm{~K}$ to ensure evaporation of the Nafion solvents yielding a loading of ca $40 \mu \mathrm{g}_{\mathrm{Pt}} \mathrm{cm}^{-2}$. Prior to any electrochemical experiment, the working electrode was immersed into the deaerated electrolyte at $E=0.10 \mathrm{~V}$ vs RHE (Ar > 99.999\%, Messer). Cyclic voltammograms were recorded in Ar-saturated electrolyte between 0.05 and $1.23 \mathrm{~V}$ vs RHE with a potential sweep rate of 0.050 or $0.020 \mathrm{~V} \mathrm{~s}^{-1}$. The real surface area was estimated using $\mathrm{CO}_{\mathrm{ad}}$ stripping coulometry assuming that the electrooxidation of a $\mathrm{CO}_{\mathrm{ads}}$ monolayer requires $420 \mu \mathrm{C}$ per $\mathrm{cm}^{2}$ of $\mathrm{Pt}$. The $\mathrm{CO}$ saturation coverage was established by bubbling $\mathrm{CO}$ for $6 \mathrm{~min}$ and purging with $\mathrm{Ar}$ for $34 \mathrm{~min}$, while keeping the electrode potential at $E=0.1 \mathrm{~V}$ vs RHE. The electrocatalytic activity for the oxygen reduction reaction was measured in $\mathrm{O}_{2}$-saturated $0.1 \mathrm{M} \mathrm{HClO}_{4}$ solution ( 20 min of purging by oxygen $>99.99 \%$, Messer) by linearly sweeping the potential from 0.40 to $1.05 \mathrm{~V}$ at a potential sweep rate of $5 \mathrm{mV} \mathrm{s}^{-1}$ and at different revolution rates $(400,900$, 1600 , and $2500 \mathrm{rpm}$ ). The ORR specific/mass activity was determined by normalizing the current measured at $E=0.95 \mathrm{~V}$ vs RHE, after correction from the oxygen diffusion in the solution and the Ohmic drop, to the real surface determined by $\mathrm{CO}_{\mathrm{ad}}$ stripping voltammetry or the mass of deposited Pt.

The accelerated stress test used to test the robustness of the nanocatalysts involved 30000 potential cycles between 0.60 and $1.00 \mathrm{~V}$ vs RHE at a potential sweep rate of $v=0.050 \mathrm{~V} \mathrm{~s}^{-1}$. The electrolyte was replaced with fresh solution after 10000 and 30000 potential cycles to perform $\mathrm{CO}_{\mathrm{ad}}$ stripping and ORR measurements. Transmission electron microscopy images of the fresh and aged reference $\mathrm{Pt} / \mathrm{C}$ electrocatalyst are displayed in Figure S2. The particle size distributions of the 30 000-cycled $\mathrm{PtNi} / \mathrm{C}$ and the reference $\mathrm{Pt} / \mathrm{C}$ electrocatalysts are displayed in Figure S3.

\section{ASSOCIATED CONTENT}

\section{S Supporting Information}

The Supporting Information is available free of charge on the ACS Publications website at DOI: 10.1021/acscatal.5b01248.

HAADF-STEM images, line scan analysis and X-EDS elemental maps of the fresh porous hollow $\mathrm{PtNi} / \mathrm{C}$ nanoparticles, and TEM images and particle size distributions of the electrocatalysts after the accelerated stress test as well as theoretical calculation of Pt surface area per mass (PDF)

\section{AUTHOR INFORMATION}

\section{Corresponding Authors}

*E-mail: laetitia.dubau@lepmi.grenoble-inp.fr (L.D.). *E-mail: frederic.maillard@lepmi.grenoble-inp.fr (F.M.).

\section{Notes}

The authors declare no competing financial interest.

\section{ACKNOWLEDGMENTS}

This work was performed within the framework of the Centre of Excellence of Multifunctional Architectured Materials "CEMAM" no. AN-10-LABX-44-01 funded by the "Investments for the Future" program. The authors acknowledge financial support from University of Grenoble-Alpes through the AGIR program (grant number LL1492017G) and from the French National Research Agency through the HOLLOW project (grant number ANR-14-CE05-0003-01) The authors are also grateful to the Région Ile-de-France for convention SESAME E1845 for the support of the JEOL ARM 200F electron microscope installed at the Paris Diderot University.

\section{REFERENCES}

(1) Kinoshita, K. J. Electrochem. Soc. 1990, 137, 845-848.

(2) Henry, C. R. Surf. Sci. Rep. 1998, 31, 231-325.

(3) Roduner, E. Chem. Soc. Rev. 2006, 35, 583-592.

(4) Maillard, F.; Pronkin, S.; Savinova, E. R. In Fuel cell catalysis: a surface science approach; Koper, M. T. M., Ed.; John Wiley \& Sons, Inc.: New York, 2009; p 507-566.

(5) Maillard, F.; Pronkin, S.; Savinova, E. R. In Handbook of fuel cells Fundamentals, technology and applications; Vielstich, W., Gasteiger, H. A., Yokokawa, H., Eds.; John Wiley \& Sons, Inc.: New York, 2009; Vol. 5 , p 91-111.

(6) Uvarov, N. F.; Boldyrev, V. V. Russ. Chem. Rev. 2001, 70, 265284

(7) Nagaev, E. L. Surf. Sci. 1991, 243, 252-260.

(8) Haruta, M. Catal. Today 1997, 36, 153-166.

(9) Valden, M.; Lai, X.; Goodman, D. W. Science 1998, 281, 16471650.

(10) Mukerjee, S. J. Appl. Electrochem. 1990, 20, 537-548.

(11) Giordano, N.; Passalacqua, E.; Pino, L.; Arico, A. S.; Antonucci, V.; Vivaldi, M.; Kinoshita, K. Electrochim. Acta 1991, 36, 1979-1984.

(12) Gloaguen, F.; Andolfatto, F.; Durand, R.; Ozil, P. J. Appl. Electrochem. 1994, 24, 863-869.

(13) Gamez, A.; Richard, D.; Gallezot, P.; Gloaguen, F.; Faure, R.; Durand, R. Electrochim. Acta 1996, 41, 307-314.

(14) Maillard, F.; Martin, M.; Gloaguen, F.; Léger, J. M. Electrochim. Acta 2002, 47, 3431-3440.

(15) Mukerjee, S. In Catalysis and Electrocatalysis at Nanoparticle Surfaces; Wieckowski, A., Savinova, E. R., Vayenas, C. G., Eds.; Marcel Dekker Inc.: New York, 2003; p 501-530.

(16) Gasteiger, H. A.; Kocha, S. S.; Sompalli, B.; Wagner, F. T. Appl. Catal., B 2005, 56, 9-35.

(17) Nesselberger, M.; Ashton, S.; Meier, J. C.; Katsounaros, I.; Mayrhofer, K. J. J.; Arenz, M. J. Am. Chem. Soc. 2011, 133, 1742817433.

(18) Perez-Alonso, F. J.; McCarthy, D. N.; Nierhoff, A.; HernandezFernandez, P.; Strebel, C.; Stephens, I. E. L.; Nielsen, J. H.; Chorkendorff, I. Angew. Chem., Int. Ed. 2012, 51, 4641-4643.

(19) Mukerjee, S.; McBreen, J. J. Electroanal. Chem. 1998, 448, 163171.

(20) Shao-Horn, Y.; Sheng, W.; Chen, S.; Ferreira, P.; Holby, E.; Morgan, D. Top. Catal. 2007, 46, 285-305. 
(21) Stamenkovic, V.; Mun, B. S.; Mayrhofer, K. J.; Ross, P. N.; Markovic, N. M.; Rossmeisl, J.; Greeley, J.; Norskov, J. K. Angew. Chem., Int. Ed. 2006, 45, 2897-2901.

(22) Stamenkovic, V. R.; Mun, B. S.; Mayrhofer, K. J.; Ross, P. N.; Markovic, N. M. J. Am. Chem. Soc. 2006, 128, 8813-8819.

(23) Stamenkovic, V. R.; Mun, B. S.; Arenz, M.; Mayrhofer, K. J. J.; Lucas, C. A.; Wang, G. F.; Ross, P. N.; Markovic, N. M. Nat. Mater. 2007, 6, 241-247.

(24) Greeley, J.; Stephens, I. E. L.; Bondarenko, A. S.; Johansson, T. P.; Hansen, H. A.; Jaramillo, T. F.; Rossmeisl, J.; Chorkendorff, I.; Nørskov, J. K. Nat. Chem. 2009, 1, 552-556.

(25) Stephens, I. E. L.; Bondarenko, A. S.; Grønbjerg, U.; Rossmeisl, J.; Chorkendorff, I. Energy Environ. Sci. 2012, 5, 6744-6762.

(26) Chen, C.; Kang, Y.; Huo, Z.; Zhu, Z.; Huang, W.; Xin, H. L.; Snyder, J. D.; Li, D.; Herron, J. A.; Mavrikakis, M.; Chi, M.; More, K. L.; Li, Y.; Markovic, N. M.; Somorjai, G. A.; Yang, P.; Stamenkovic, V. R. Science 2014, 343, 1339-1343.

(27) Paffett, M. T.; Daube, K. A.; Gottesfeld, S.; Campbell, C. T. J. Electroanal. Chem. Interfacial Electrochem. 1987, 220, 269-285.

(28) Bardi, U.; Beard, B. C.; Ross, P. N. J. Vac. Sci. Technol., A 1988, 6, 665-670.

(29) Paffett, M. T.; Beery, J. G.; Gottesfeld, S. J. Electrochem. Soc. 1988, 135, 1431-1436.

(30) Hammer, B.; Nørskov, J. K. Surf. Sci. 1995, 343, 211-220.

(31) Gauthier, Y.; Joly, Y.; Baudoing, R.; Rundgren, J. Phys. Rev. B: Condens. Matter Mater. Phys. 1985, 31, 6216-6218.

(32) Kitchin, J. R.; Norskov, J. K.; Barteau, M. A.; Chen, J. G. Phys. Rev. Lett. 2004, 93, 156801.

(33) Bligaard, T.; Nørskov, J. K. Electrochim. Acta 2007, 52, 55125516.

(34) Dubau, L.; Maillard, F.; Chatenet, M.; Guétaz, L.; André, J.; Rossinot, E. J. Electrochem. Soc. 2010, 157, B1887-B1895.

(35) Dubau, L.; Maillard, F.; Chatenet, M.; André, J.; Rossinot, E. Electrochim. Acta 2010, 56, 776-783.

(36) Chen, S.; Gasteiger, H. A.; Hayakawa, K.; Tada, T.; Shao-Horn, Y. J. Electrochem. Soc. 2010, 157, A82-A97.

(37) Dubau, L.; Lopez-Haro, M.; Castanheira, L.; Durst, J.; Chatenet, M.; Bayle-Guillemaud, P.; Guétaz, L.; Caqué, N.; Rossinot, E.; Maillard, F. Appl. Catal., B 2013, 142-143, 801-808.

(38) Lopez-Haro, M.; Dubau, L.; Guétaz, L.; Bayle-Guillemaud, P.; Chatenet, M.; André, J.; Caqué, N.; Rossinot, E.; Maillard, F. Appl. Catal., B 2014, 152-153, 300-308.

(39) Dubau, L.; Castanheira, L.; Maillard, F.; Chatenet, M.; Lottin, O.; Maranzana, G.; Dillet, J.; Lamibrac, A.; Perrin, J. C.; Moukheiber, E.; Elkaddouri, A.; De Moor, G.; Bas, C.; Flandin, L.; Caqué, N. Wiley Interdiscip. Rev.: Energy Environ. 2014, 3, 540-560.

(40) Dubau, L.; Durst, J.; Maillard, F.; Guétaz, L.; Chatenet, M.; André, J.; Rossinot, E. Electrochim. Acta 2011, 56, 10658-10667.

(41) Wang, C.; Chi, M.; Li, D.; Strmcnik, D.; Van Der Vliet, D.; Wang, G.; Komanicky, V.; Chang, K. C.; Paulikas, A. P.; Tripkovic, D.; Pearson, J.; More, K. L.; Markovic, N. M.; Stamenkovic, V. R. J. Am. Chem. Soc. 2011, 133, 14396-14403.

(42) Snyder, J.; McCue, I.; Livi, K.; Erlebacher, J. J. Am. Chem. Soc. 2012, 134, 8633-8645.

(43) Greszler, A.; Moylan, T.; Gasteiger, H. A. In Handbook of fuel cells - Fundamentals, technology and applications; Vielstich, W., Gasteiger, H. A., Yokokawa, H., Eds.; John Wiley \& Sons: Chichester, 2009; Vol. 4, p 728-748.

(44) Durst, J.; Chatenet, M.; Maillard, F. Phys. Chem. Chem. Phys. 2012, 14, 13000-13009.

(45) Jia, Q. Y.; Ramaker, D. E.; Ziegelbauer, J. M.; Ramaswamy, N.; Halder, A.; Mukerjee, S. J. Phys. Chem. C 2013, 117, 4585-4596.

(46) Kirkendall, E.; Thomassen, L.; Uethegrove, C. Trans. AIME 1939, 133, 186-203.

(47) Kirkendall, E. O. Trans. AIME 1942, 147, 104-109.

(48) Smigelskas, A. D.; Kirkendall, E. O. Trans. AIME 1947, 171, $130-142$.

(49) González, E.; Arbiol, J.; Puntes, V. F. Science 2011, 334, 13771380.
(50) Wang, J. X.; Ma, C.; Choi, Y.; Su, D.; Zhu, Y.; Liu, P.; Si, R.; Vukmirovic, M. B.; Zhang, Y.; Adzic, R. R. J. Am. Chem. Soc. 2011, 133, 13551-13557.

(51) Zhang, Y.; Ma, C.; Zhu, Y. M.; Si, R.; Cai, Y.; Wang, J. X.; Adzic, R. R. Catal. Today 2013, 202, 50-54.

(52) Dubau, L.; Lopez-Haro, M.; Durst, J.; Guetaz, L.; BayleGuillemaud, P.; Chatenet, M.; Maillard, F. J. Mater. Chem. A 2014, 2, 18497-18507.

(53) Shan, A.; Chen, Z.; Li, B.; Chen, C.; Wang, R. J. Mater. Chem. A 2015, 3, 1031-1036.

(54) Durst, J.; Lopez-Haro, M.; Dubau, L.; Chatenet, M.; SoldoOlivier, Y.; Guétaz, L.; Bayle-Guillemaud, P.; Maillard, F. J. Phys. Chem. Lett. 2014, 5, 434-439.

(55) Strmcnik, D. S.; Tripkovic, D. V.; van der Vliet, D.; Chang, K. C.; Komanicky, V.; You, H.; Karapetrov, G.; Greeley, J.; Stamenkovic, V. R.; Markovic, N. M. J. Am. Chem. Soc. 2008, 130, 15332-15339.

(56) Clavilier, J.; Faure, R.; Guinet, G.; Durand, R. J. Electroanal. Chem. Interfacial Electrochem. 1979, 107, 205-209.

(57) Markovic, N. M.; Ross, P. N. Surf. Sci. Rep. 2002, 45, 117-229.

(58) Vidal-Iglesias, F. J.; Aran-Ais, R. M.; Solla-Gullon, J.; Herrero, E.; Feliu, J. M. ACS Catal. 2012, 2, 901-910.

(59) Ciapina, E. G.; Santos, S. F.; Gonzalez, E. R. J. Electroanal. Chem. 2010, 644, 132-143.

(60) Maillard, F.; Eikerling, M.; Cherstiouk, O. V.; Schreier, S.; Savinova, E.; Stimming, U. Faraday Discuss. 2004, 125, 357-377.

(61) Maillard, F.; Schreier, S.; Hanzlik, M.; Savinova, E. R.; Weinkauf, S.; Stimming, U. Phys. Chem. Chem. Phys. 2005, 7, 385-393.

(62) Maillard, F.; Savinova, E. R.; Stimming, U. J. Electroanal. Chem. 2007, 599, 221-232.

(63) Ruban, A.; Hammer, B.; Stoltze, P.; Skriver, H. L.; Nørskov, J. K. J. Mol. Catal. A: Chem. 1997, 115, 421-429.

(64) Freund, L. B.; Suresh, S. Thin films materials: stress, defect formation and surface evolution; Cambridge University Press, 2006; p 750 .

(65) Matthews, J. W.; Blakeslee, A. E. J. Cryst. Growth 1974, 27, 118125.

(66) Li, D.; Wang, C.; Strmcnik, D. S.; Tripkovic, D. V.; Sun, X.; Kang, Y.; Chi, M.; Snyder, J. D.; van der Vliet, D.; Tsai, Y.; Stamenkovic, V. R.; Sun, S.; Markovic, N. M. Energy Environ. Sci. 2014, 7, 4061-4069.

(67) Fievet, F.; Lagier, J. P.; Figlarz, M. MRS Bull. 1989, 14, 29-34.

(68) Oh, H.-S.; Oh, J.-G.; Kim, H. J. Power Sources 2008, 183, 600603.

(69) Oh, H.-S.; Oh, J.-G.; Hong, Y.-G.; Kim, H. Electrochim. Acta 2007, 52, 7278-7285.

(70) Ricolleau, C.; Nelayah, J.; Oikawa, T.; Kohno, Y.; Braidy, N.; Wang, G.; Hue, F.; Florea, L.; Pierron Bohnes, V.; Alloyeau, D. Microscopy 2013, 62, 283-293.

(71) Herrmann, C. C.; Perrault, G. G.; Pilla, A. A. Anal. Chem. 1968, $40,1173-1174$. 